\title{
Effectiveness of Fall versus Spring Soil Fertilization of Field-grown Peach Trees
}

\author{
F.J.A. Niederholzer, ${ }^{1}$ T.M. DeJong, J.-L. Saenz, ${ }^{2}$ T.T. Muraoka, and S.A. Weinbaum ${ }^{3}$ \\ Department of Pomology, University of California, Davis, CA 95616-8683
}

\begin{abstract}
Additional Index words. Prunus persica, nitrogen fertilization, nitrogen remobilization, nitrogen storage, nitrogen uptake
Abstract. Marginally nitrogen (N)-deficient, field-grown peach trees [Prunus persica (L.) Batsch (Peach Group) ' $O$ ' Henry'] were used to evaluate seasonal patterns of tree $\mathrm{N}$ uptake, vegetative growth, and yield following fall or spring fertilization. Sequential tree excavations and determinations of tree biomass and $\mathbf{N}$ contents in Feb. and Aug. allowed estimation of $\mathrm{N}$ uptake by fall-fertilized trees between September 1993 and mid-February 1994. Total $\mathrm{N}$ uptake (by difference) by spring-fertilized trees as well as additional $\mathrm{N}$ uptake by fall-fertilized trees over the spring-summer period was also determined. In fall-fertilized trees, only $24 \%$ of tree $\mathrm{N}$ accumulation between September 1993 and August 1994 occurred during the fall/dormancy period. Spring- and fall-fertilized trees exhibited comparable vegetative growth, fruit size, and yield despite lower dormant tree $\mathrm{N}$ contents and tissue $\mathrm{N}$ concentrations in the spring-fertilized trees. Fifty percent of tree leaf $\mathbf{N}$ content was available for resorption from leaves for storage in woody tree parts. This amount $(\mathbf{N}$ at $\approx 30 \mathrm{~kg} \cdot \mathrm{ha}^{-1}$ ) was calculated to represent more than $80 \%$ of the $\mathrm{N}$ storage capacity in perennial tree parts of fertilized peach trees. Our data suggest that leaf $N$ resorption, even without fall soil $N$ application, can provide sufficient $N$ from storage to initiate normal growth until plant-available soil $\mathbf{N}$ is accessed in spring.
\end{abstract}

The annual, cyclical accumulation of $\mathrm{N}$ in woody tissues of mature deciduous fruit trees in fall and the redistribution of stored $\mathrm{N}$ during growth resumption in spring has long been recognized (Roberts, 1921; Titus and Kang, 1982). The relationship between the timing of fertilizer $\mathrm{N}$ application and tree responses to those application periods has remained controversial. Although $\mathrm{N}$ uptake and tree response to the timing of fertilizer applications may vary with soil type and air temperature (Sanchez et al., 1990; Weinbaum et al., 1984), it appears that a primary source of the controversy may be differential responses to fertilizer timing between mature, fieldgrown trees and immature trees. A number of researchers have expressed concern that extrapolation from studies using immature trees to mature, field-grown trees may be inappropriate (Millard, 1996; Oland, 1959; Taylor and van den Ende, 1969).

The interrelationships among the timing of fertilizer $\mathrm{N}$ applications, tree $\mathrm{N}$ uptake, $\mathrm{N}$ storage, yield, and vegetative growth have received little study in mature trees. We have attempted to fill that gap by using field-grown, marginally $\mathrm{N}$-deficient 'O'Henry' peach [Prunus persica (Peach Group)] trees, and excavating whole trees to address quantitatively both tree capacity for $\mathrm{N}$ uptake and tree performance following fall vs. spring applications of fertilizer $\mathrm{N}$. Marginally N-deficient trees were used to promote N uptake following fertilization (Youssefi et al., 2000a). Our general objective was to reconcile the controversy in the literature regarding the comparative impact of fall vs. spring-applied fertilizer $\mathrm{N}$ on tree growth and yield. Our specific objectives were to assess a) tree $\mathrm{N}$ accumulation and usage by mature, field-grown peach trees following soil application of fertilizer $\mathrm{N}$ in either the fall (postharvest) or the spring, b) the effect of fall vs. spring fertilization on vegetative growth and

Received for publication 27 Dec. 2000. Accepted for publication 17 June 2001 We acknowledge assistance of A. Bonin, T. Cristler, R. Rosecrance, and H. Sampson. We also appreciate the constructive comments of L. Cheng, R.S. Johnson, and E. Sanchez as well as critical reviews of and earlier draft of this manuscript by D. Huett, I. Klein, and D. Neilson. The cost of publishing this paper was defrayed in part by the payment of page charges. Under postal regulations, this paper therefore must be hereby marked advertisement solely to indicate this fact.

${ }^{1}$ Current address: 602 First Avenue, Orlando, CA 95693

${ }^{2}$ Current address: Dept. of Fruit Science, Southwest Missouri State University, Mountain Grove, MO 65711-9252.

${ }^{3}$ Corresponding author; e-mail saweinbaum@ucdavis.edu. yield, and c) the relative contributions to storage of net leaf $\mathrm{N}$ resorption before natural leaf fall vs. postharvest root uptake of $\mathrm{N}$.

\section{Materials and Methods}

'O'Henry' peach trees grafted on 'Lovell' rootstock were planted in January 1989 in a commercial setting at the University of California's Wolfskill Experimental Orchard near Winters, Calif. (lat. 38 $32^{\prime} \mathrm{N}$, long. $121^{\circ} 58^{\prime} \mathrm{W}$ ). The soil at the site is a Yolo clay loam (fine-silty, mixed, nonacid, thermic Typic Xerorthents). Trees were spaced $1.8 \mathrm{~m}$ apart within the row and $5.15 \mathrm{~m}$ between rows (1055 trees/ha). Tree canopies were trained to the KAC-V (DeJong, et al., 1994), a system in which two scaffold branches per tree were trained perpendicular to the tree row. Trees were 3 to $4 \mathrm{~m}$ tall at the time of the experiment.

All trees involved in the study presented herein were part of a large (858 tree) $\mathrm{N}$ fertilization study (Saenz, et al., 1997) involving four fertilizer and three thinning treatments. Each fertilizer treatment plot consisted of 45 trees (five rows of nine trees each) and was replicated four times. Thinning treatments, each consisting of one row of seven trees, were nested as subplots within the fertilizer treatments. Guard trees separated fertilizer treatments within and across tree rows.

The study described in this paper utilized individual trees from the larger study. Selection of these trees was based on uniform tree size as determined by similar trunk diameters (Chalmers and van den Ende, 1975; Westwood and Roberts, 1970). Experiment and statistical analysis followed a completely randomized design.

All study trees received no fertilizer in 1993 prior to Sept. 29. In Sept. 1993, leaf N deficiency symptoms were visible throughout the orchard, and leaf analyses $[<2.1 \%$ leaf $\mathrm{N}$ on a dry weight (DW) basis] confirmed that trees were marginally $\mathrm{N}$-deficient according to Beutel et al., (1983) as of 27 Sept.1993.

Three fertilizer treatments were established between 29 Sept. 1993 and 9 Apr. 1994. Study trees received either no fertilizer N, N at $200 \mathrm{~kg} \cdot \mathrm{ha}^{-1}$ on 29 Sept. 1993, or N at $200 \mathrm{~kg} \cdot \mathrm{ha}^{-1}$ on $9 \mathrm{Apr} .1994$. Fertilizer $\mathrm{N}$ was applied manually as $\mathrm{NH}_{4} \mathrm{NO}_{3}$ around each tree and immediately incorporated by irrigation.

On 15 Feb. 1994, eight trees-four trees previously receiving a fall application of $\mathrm{N}$ at $200 \mathrm{~kg} \cdot \mathrm{ha}^{-1}$ and four trees receiving no $\mathrm{N}-$ 
were excavated using a backhoe. Fine roots were separated from soil using pitchforks and shovels, and rinsed with water to remove adhering soil. While some percentage of the fibrous root biomass was undoubtedly lost, this method of excavation captured the vast majority of root biomass (virtually all roots $>1 \mathrm{~cm}$ diameter), and, thus, should not have altered the results or interpretation of the experiment. We suggest that the percentage of tree $\mathrm{N}$ content in the fibrous roots of our experimental trees was considerably less than the small percentage of tree $\mathrm{N}$ content in fibrous roots reported by Munoz et al. (1993) for young, sand-cultured peach trees. The trees were separated into the following components: roots (all tissue below the graft union), trunk, and branches. Fresh weights (FWs) of each tree component were determined in the field. Branches, trunks, and woody roots were then chipped using an industrial chipper, and one subsample ( $\approx 10 \%$ of the total $\mathrm{FW}$ of each component) for each component was dried at $70{ }^{\circ} \mathrm{C}$ in forced air ovens to establish the FW:DW ratio. Total FW was divided by this ratio to calculate the DW of each tree part. Total tree DW was calculated as the sum of the DW of the various tree parts.

Dried samples were ground to pass a 30-mesh (0.847) screen and analyzed for N. Nitrogen was determined by conductimetric analyses following micro-Kjeldahl digestion (Carlson, 1978). Tree N content was calculated as the sum of the products of tree part DW $\times$ tissue $\mathrm{N}$ concentration for that tree part.

Three to four weeks after full bloom, all remaining study trees were thinned to a commercial crop load of $\approx 200$ fruit per tree. No noticeable fruit drop (June drop) occurred under any of the treatments between thinning and harvest.

The orchard was maintained following standard commercial practices for pest and weed control. Irrigation was provided by microsprinklers on a weekly basis to replace $100 \%$ of estimated crop water use based on a standard reference pan located within $400 \mathrm{~m}$ of the study orchard.

In early June, all trees were summer-pruned. Summer prunings were not separated by tree within each seven-tree thinning $\times$ fertilizer treatment, but bulked for those seven trees. Thus, our data for summer pruning DWs and $\mathrm{N}$ contents are averages of those seven adjacent trees, and not specific to the study tree(s) contained in that thinning $\times$ fertilizer treatment replicate. Immediately following summer pruning, total pruning FW (for bulked tissue) was determined, and then a subsample $(\approx 10 \%$ of total $\mathrm{FW})$ was taken and weighed. Subsamples were separated into leaves and stem tissue, and FW for each were measured. The subsamples were taken to the laboratory and dried at $70{ }^{\circ} \mathrm{C}$. Nitrogen concentrations (percentage DW) of the samples were determined using the methods described above. Total summer pruning $\mathrm{N}$ and DW contents for the bulked seven-tree samples were determined as described previously. These bulked sample values were divided by seven (the number of trees per thinning $\times$ fertilizer treatment replicate) to obtain the final values for individual study tree summer pruning leaf and stem tissue DW and $\mathrm{N}$ contents.

Fruit were harvested at commercial maturity between 28 July and 18 Aug. 1994. Fruit FWs per tree were obtained at each harvest date, and subsamples $(n=10)$ from each harvest taken to establish a DW:FW ratio. In the laboratory, fruit were separated into mesocarp plus exocarp, endocarp, and kernel. FWs of the three fractions were determined and DWs obtained after drying at $70^{\circ} \mathrm{C}$ in forced air ovens. Dried tissue was pulverized using a consumer coffee grinder (Braun Aromatic KSM 2, The Gillette Company, Boston), and $\mathrm{N}$ concentrations determined in each tissue as described below. Total fruit DW per tree was determined by adding together the products of the DW:FW ratio and total FW harvested for each of the three fruit parts. Similarly, total fruit N content was determined as the sum of the products of tissue $\mathrm{N}$ concentration (percentage DW) and the total DW for each fruit part.

On 23 Aug. 1994, three trees from each fertilizer treatment (total of nine trees) were excavated and separated into the following components: roots (all tissue below the graft union), trunk and branches, current year stems, and leaves. Excavation, total FW measurements, and FW subsample measurements were all performed as described for the 15 Feb. excavation. Subsamples were dried and weighed as described previously within the protocol used for dormant tree excavation. Tissue $\mathrm{N}$ concentrations (percentage DW) were determined as described above. Whole tree $\mathrm{N}$ and dry matter contents were determined using the process described previously. DWs and $\mathrm{N}$ contents of harvested fruit and summer prunings were added to excavated tree values to obtain the whole tree DW and $\mathrm{N}$ content values presented as $23 \mathrm{Aug}$. excavation data.

Fertilization-associated tree $\mathrm{N}$ uptake was calculated as the difference in tree $\mathrm{N}$ contents between fertilized trees and nonfertilized trees on 15 Feb. and 23 Aug. This value may include both fertilizer $\mathrm{N}$ and $\mathrm{N}$ released from organic forms in response to the application of fertilizer N (see Jenkinson et al., 1985). Tree N accumulation may also reflect uptake of indigenous soil $\mathrm{N}$ released as a result of net mineralization. Estimated efficiency of $\mathrm{N}$ recovery (EENR) was calculated as the difference in tree $\mathrm{N}$ contents between fertilized and nonfertilized trees on $15 \mathrm{Feb}$. and $23 \mathrm{Aug}$. divided by the amount of fertilizer $\mathrm{N}$ applied (190 g/tree).

Statistical analyses of whole and partitioned tree $\mathrm{N}$ and dry matter contents, concentrations and percentage dry matter and $\mathrm{N}$ distribution within trees were conducted using analysis of variance (SAS Inst. Inc., Cary, N.C.), and treatment means separated by F test (dormant) or Tukey's Studentized range test.

\section{Results}

Fall Fertilization AND LATE SEASON N UPTAKe. Fall N fertilization visibly delayed leaf senescence and abscission, increased tissue $\mathrm{N}$ concentrations, increased root $\mathrm{DW}$, and increased the $\mathrm{N}$ contents of dormant trees by approximately 50\% (73 vs. $46 \mathrm{~g} /$ tree) vs. nonfertilized trees (Table 1). Above-ground and total tree DWs did not differ significantly between fall-fertilized and nonfertilized trees (Table 1).

Nitrogen uptake associated with fall fertilization and during the

Table 1. Effects of fall fertilization on $\mathrm{N}$ concentration, tree dry matter, and $\mathrm{N}$ contents of field-grown 'O'Henry' peach trees during dormancy. ${ }^{\mathrm{z}}$

\begin{tabular}{|c|c|c|c|c|c|c|}
\hline \multirow[b]{2}{*}{ Tissue } & \multicolumn{2}{|c|}{$\mathrm{N}$ concn $(\% \text { dry wt })^{\mathrm{y}}$} & \multicolumn{2}{|c|}{ Dry matter $(\mathrm{kg} / \mathrm{tree})$} & \multicolumn{2}{|c|}{$\mathrm{N}$ content (g/tree) } \\
\hline & No N & Fall N & No N & Fall N & No N & Fall N \\
\hline Trunk and branches & $0.23 \mathrm{~b}$ & $0.27 \mathrm{a}$ & $8.4 \mathrm{a}$ & $8.4 \mathrm{a}$ & $19.1 \mathrm{~b}$ & $22.4 \mathrm{a}$ \\
\hline Roots & $0.52 \mathrm{~b}$ & $0.84 \mathrm{a}$ & $5.2 \mathrm{~b}$ & $6.0 \mathrm{a}$ & $26.8 \mathrm{~b}$ & $50.9 \mathrm{a}$ \\
\hline Total & --- & --- & $13.6 \mathrm{a}$ & $14.5 \mathrm{~b}$ & $46.0 \mathrm{~b}$ & $73.4 \mathrm{a}$ \\
\hline
\end{tabular}

${ }^{\mathrm{z} F a l l ~ f e r t i l i z a t i o n ~ o c c u r r e d ~ o n ~} 29$ Sept. 1993, and trees were excavated during dormancy (15 Feb. 1994).

${ }^{y}$ For each parameter, mean $(\mathrm{n}=4)$ separation in rows by $\mathrm{F}$ test $(P \leq 0.05)$. 
Table 2. Effect of fertilization and fertilization timing on temporal patterns of tree $\mathrm{N}$ accumulation and estimated efficiency of $\mathrm{N}$ recovery (EENR). ${ }^{\mathrm{Z}}$

\begin{tabular}{|c|c|c|c|c|c|c|}
\hline & \multicolumn{6}{|c|}{ Tree $\mathrm{N}$ accumulation } \\
\hline & \multicolumn{3}{|c|}{ Fall/winter (29 Sept. -15 Feb.) } & \multicolumn{3}{|c|}{ Spring/summer (15 Feb.-23 Aug.) } \\
\hline Treatment & $\begin{array}{c}\text { Fertilization- } \\
\text { associated } \\
\mathrm{N} \\
(\mathrm{g} / \mathrm{tree})\end{array}$ & $\begin{array}{c}\text { Native } \\
\mathrm{N} \\
\text { (g/tree) }\end{array}$ & $\begin{array}{c}\text { EENR }^{\mathrm{y}} \\
(\%)\end{array}$ & $\begin{array}{c}\text { Fertilization- } \\
\text { associated } \\
\mathrm{N} \\
(\mathrm{g} / \text { tree })\end{array}$ & $\begin{array}{c}\text { Native } \\
\mathrm{N} \\
\text { (g/tree) }\end{array}$ & $\begin{array}{c}\text { EENR } \\
(\%)\end{array}$ \\
\hline$\overline{\mathrm{No} N}$ & 0.0 & $\mathrm{ND}^{\mathrm{x}}$ & --- & 0.0 & $50.5^{\mathrm{w}}$ & --- \\
\hline Fall N & 27.4 & ND & 14.4 & 111.7 & ND & 58.8 \\
\hline Spring N & --- & --- & --- & 95.0 & ND & 50.0 \\
\hline
\end{tabular}

${ }^{\mathrm{z}}$ Data based on tree excavations during dormancy $(n=4 ; 15$ Feb. 1994) and following harvest $(n=3 ; 23$ Aug. 1994).

${ }^{y}$ EENR = estimated efficiency of $\mathrm{N}$ recovery; calculated as the difference in tree $\mathrm{N}$ contents between fertilized and nonfertilized trees on 15 Feb. and 23 Aug. divided by the amount of fertilizer N applied (190 g/tree).

${ }^{\mathrm{x}} \mathrm{ND}=$ not determined. Uptake of indigenous soil $\mathrm{N}$ could not be determined because we did not excavate and analyze nonfertilized trees to establish a tree $\mathrm{N}$ content baseline at the onset of experimentation on 29 Sept. 1993 and, therefore, could not determine $\mathrm{N}$ accumulation by nonfertilized trees between 29 Sept. 1993 and 15 Feb. 1994.

${ }^{\mathrm{w}}$ Apparent uptake of native soil $\mathrm{N}$ by nonfertilized trees. Value was calculated as the difference in the $\mathrm{N}$ contents of nonfertilized trees excavated on 15 Feb. and 23 Aug. 1994.

period of 29 Sept. 1993 to 15 Feb. 1994, was calculated to be $27 \mathrm{~g} /$ tree $\left(\mathrm{N}\right.$ at $\left.29 \mathrm{~kg} \cdot \mathrm{ha}^{-1}\right)$ from the difference in tree $\mathrm{N}$ contents between fall-fertilized and nonfertilized trees ( $\mathrm{N}$ at 46 to $73 \mathrm{~g} /$ tree, Table 1) at the time of tree excavation on 15 Feb.

The estimated percentage recovery of fall-applied $\mathrm{N}$ between the time of application 29 Sept. and late dormancy (15 Feb.) was $14.4 \%$ (calculated as the difference in $\mathrm{N}$ contents between fertilized and nonfertilized trees on 15 Feb., divided by $190 \mathrm{~g}$ of fertilizer $\mathrm{N}$ applied per tree; Table 2). This value may slightly underestimate $\mathrm{N}$ uptake during fall- to the extent that fall-applied $\mathrm{N}$ was translocated to the leaves and carried to the orchard floor in the leaf litter following abscission.

NITROGEN UPTAKE DURING SPRING/SUMMER. Nonfertilized trees accumulated $50 \mathrm{~g}$ of native soil $\mathrm{N}$ per tree during spring and summer (Table 2). Their pale green foliage indicative of $\mathrm{N}$ deficiency was observed throughout the 1994 growing season (data not presented, but see Saenz, et al., 1997). Nitrogen accumulation by fall-fertilized trees continued during the following spring and summer, and fall- and springfertilized trees accumulated 112 and $95 \mathrm{~g} \mathrm{~N} /$ tree, respectively, between 15 Feb. and 23 Aug. 1994 (Table 2). Calculations made after tree excavations on 23 Aug. and tissue processing indicated that the estimated efficiency of $\mathrm{N}$ recovery (EENR) was between $50 \%$ and $60 \%$ in both fall- and spring-fertilized trees (Table 2).

EFFECT OF FERTILIZATION AND FERTILIZATION TIMING ON LEAF $\mathbf{N}$ CONTENT AND LEAF AREA PER TREE. Fertilization increased leaf N content per tree by more than $100 \%$ as a result, primarily, of the $100 \%$ increase in leaf area per tree. Fertilization also increased $\mathrm{N}$ content per unit leaf area by $\approx 10 \%$ to $20 \%$ (Table 3 ). The timing of fertilizer applications (i.e., in fall or spring) did not influence leaf area per tree or leaf $\mathrm{N}$ content per tree, but leaf $\mathrm{N}$ content per unit area was about $8 \%$ higher in spring- than in fall-fertilized trees.

EFFECT OF FERTILIZATION AND FERTILIZATION TIMING ON TISSUE N CONCENTRATIONS AND TREE N DISTRIBUTION. Nitrogen fertilization increased the relative percentage of tree dry matter allocated to current-year stems and leaves, i.e., current year, above-ground vegetative growth, but not to other tree parts (Table 4). At the time of postharvest tree excavation, dry matter of current-year stems and leaves was $>100 \%$ greater in fertilized than nonfertilized trees (Table 4). Fruit and current-season shoots (i.e., stems and leaves) contained from $50 \%$ to $82 \%$ of the total $N$ content per tree at the time of tree excavation in August, but only contained about a third of the tree's dry matter (Table 4).

\section{Discussion}

The present experiment was conducted to help resolve the controversy in the literature concerning the relationship between the timing of fertilizer $\mathrm{N}$ applications and subsequent performance of deciduous fruit trees. Tree $\mathrm{N}$ uptake appeared somewhat greater following a fall application than following spring fertilization (Table 2), but no differences were apparent in yield and fruit growth (Saenz et al, 1997) or vegetative growth (Table 3 ) between marginally $\mathrm{N}$-deficient fall- and spring-fertilized field-grown peach trees. The preponderance of studies in which the timing of fertilizer applications affected tree responses including the amount of extension growth, bloom quality, percentage fruit set, and yield have been associated with use of young, potted trees grown in sand culture (Hill-Cottingham, 1963; Taylor et al., 1975; Williams, 1965). A lack of response by mature, field-grown trees to fertilizer timing has been reported previously (Huett and Stewart, 1999; Magness et al.,

Table 3. Effect of fertilization and the timing of fertilizer applications on leaf area per tree $\left(\mathrm{m}^{2} /\right.$ tree $), \mathrm{N}$ content per unit leaf area $\left(\mathrm{g} \cdot \mathrm{m}^{-2}\right)$, leaf $\mathrm{N}$ content per tree, and leaf $\mathrm{N}$ content per ha at the time of tree excavation on 23 Aug. 1994.

\begin{tabular}{|c|c|c|c|c|c|}
\hline \multirow[b]{2}{*}{ Treatment } & \multirow{2}{*}{$\begin{array}{l}\text { Leaf area } \\
\left(\mathrm{m}^{2} / \text { tree }\right)\end{array}$} & \multirow{2}{*}{$\begin{array}{c}\text { No. of } \\
\text { trees }\end{array}$} & \multicolumn{3}{|c|}{ Leaf $\mathrm{N}$ content } \\
\hline & & & $\left(\mathrm{g} \cdot \mathrm{m}^{-2}\right)$ & (g/tree) & $\left(\mathrm{kg} \cdot \mathrm{ha}^{-1}\right)$ \\
\hline No N & $13.9 \mathrm{~b}^{\mathrm{z}}$ & 3 & $1.8 \mathrm{~b}$ & $25.5 \mathrm{~b}$ & $26.9 \mathrm{~b}$ \\
\hline Fall $\mathrm{N}^{\mathrm{y}}$ & $30.0 \mathrm{a}$ & 3 & $2.0 \mathrm{~b}$ & $60.1 \mathrm{a}$ & $63.5 \mathrm{a}$ \\
\hline Spring $\mathrm{N}^{\mathrm{x}}$ & $28.7 \mathrm{a}$ & 3 & $2.2 \mathrm{a}$ & $62.4 \mathrm{a}$ & $65.8 \mathrm{a}$ \\
\hline
\end{tabular}

${ }^{\mathrm{z}}$ Mean separation within columns by Tukey's studentized range test.

${ }^{\mathrm{y}}$ Applied 29 Sept. 1993.

xApplied 9 Apr. 1994. 
Table 4. Effect of fertilization and fertilization timing on tissue $\mathrm{N}$ concentrations, dry matter, and $\mathrm{N}$ distribution in field-grown 'O'Henry' peach trees after harvest. ${ }^{\mathrm{z}}$

\begin{tabular}{|c|c|c|c|c|c|c|c|c|c|}
\hline \multirow[b]{2}{*}{ Tissue } & \multicolumn{3}{|c|}{$\mathrm{N}$ concn (\% dry wt) } & \multicolumn{3}{|c|}{ Dry matter (kg/tree) } & \multicolumn{3}{|c|}{$\mathrm{N}$ content ( $\mathrm{g} /$ tree $)$} \\
\hline & No N & Fall N & Spring N & No N & Fall N & Spring N & No N & Fall N & Spring N \\
\hline Trunks and branches & $0.17 \mathrm{a}^{\mathrm{x}}$ & $0.18 \mathrm{a}$ & $0.18 \mathrm{a}$ & $12.2 b^{x}$ & $15.1 \mathrm{a}$ & $12.3 \mathrm{a}$ & $20.7 b^{x}$ & $27.7 \mathrm{a}$ & $22.8 \mathrm{a}$ \\
\hline Roots & $0.36 \mathrm{~b}$ & $0.52 \mathrm{a}$ & $0.52 \mathrm{a}$ & $5.1 \mathrm{a}$ & $5.5 \mathrm{a}$ & $4.6 \mathrm{a}$ & $18.4 \mathrm{a}$ & $29.0 \mathrm{a}$ & $23.7 \mathrm{a}$ \\
\hline Stems $^{\mathrm{y}}$ & $1.02 \mathrm{a}$ & $1.16 \mathrm{a}$ & $1.23 \mathrm{a}$ & $0.5 \mathrm{~b}$ & $1.5 \mathrm{a}$ & $1.4 \mathrm{a}$ & $4.1 \mathrm{~b}$ & $14.1 \mathrm{a}$ & $15.1 \mathrm{a}$ \\
\hline Leaves $^{y}$ & $2.05 \mathrm{~b}$ & $2.45 \mathrm{a}$ & $2.75 \mathrm{a}$ & $1.5 \mathrm{~b}$ & $3.2 \mathrm{a}$ & $2.9 \mathrm{a}$ & $31.2 \mathrm{~b}$ & $85.3 \mathrm{a}$ & $86.4 \mathrm{a}$ \\
\hline Fruit & $0.49 \mathrm{~b}$ & $0.78 \mathrm{a}$ & $0.79 \mathrm{a}$ & $5.1 \mathrm{~b}$ & $6.5 \mathrm{a}$ & $5.9 \mathrm{ab}$ & $22.1 \mathrm{~b}$ & $52.2 \mathrm{a}$ & $43.5 \mathrm{ab}$ \\
\hline Total (g/tree) & --- & --- & --- & --- & --- & --- & $96.5 \mathrm{~b}$ & $208.2 \mathrm{a}$ & $191.6 \mathrm{ab}$ \\
\hline Total (kg/tree) & --- & --- & --- & $24.4 \mathrm{~b}$ & $31.9 \mathrm{a}$ & $27.1 \mathrm{ab}$ & --- & --- & --- \\
\hline
\end{tabular}

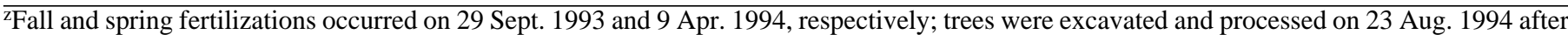
harvest.

${ }^{\mathrm{N}} \mathrm{N}$ Content and dry matter data include summer prunings.

xMean separation within columns by Tukey's studentized range test, $P \leq 0.05$.

1948; Weinberger and Cullinan, 1934), and we are unaware of any reports to the contrary when mature trees have been studied. We hypothesize, therefore, that the controversy is based on the differential responses to $\mathrm{N}$ fertilizer timing between immature and mature trees and offer three possible explanations for this discrepancy. First, the larger pool of storage $\mathrm{N}$ in mature relative to immature trees and its greater significance relative to external inputs has been suggested (Millard and Nielsen,1989; Miller, 1986). As trees age, the importance of internal cycling relative to external inputs increases, i.e., trees become less dependent upon soil $\mathrm{N}$ uptake. Second, the greater likelihood of persistence of fertilizer $\mathrm{N}$ in field soils relative to coarse sands following application, and third, the availability and significance of native soil $\mathrm{N}$ would appear to buffer the orchard system (Schaffers, 2000) against a very limited window of soil $\mathrm{N}$ availability which may occur when nutrient solutions are supplied to young, potted trees grown in sterile sand. In field soils, more than $90 \%$ of total soil $\mathrm{N}$ is organically bound, and $1 \%$ to $3 \%$ of that may be mineralized each year (Amberger, 1983).

Our experimental protocol optimized tree capacity for both uptake of fall-applied $\mathrm{N}$ as well as tree response to that application. The protocol included use of marginally $\mathrm{N}$-deficient trees and a supraoptimal $\mathrm{N}$ application rate. Marginally $\mathrm{N}$-deficient trees were used to a) increase tree capacity for soil N uptake (Taylor et al., 1975; Youssefi et al., 2000a, 2000b), b) limit the impact of reserve $\mathrm{N}$ on subsequent tree performance (Tromp and Ovaa, 1985), and c) avoid high levels of soil $\mathrm{N}$ independent of the fall and spring applications of fertilizer $\mathrm{N}$.

Also, a year of below-average winter rainfall was likely associated with reduced denitrification and leaching and may have contributed to the persistence in the soil of the fall-applied $\mathrm{N}$ into the subsequent spring and summer. Winter rains were only $70 \%$ of the 30 year average onsite precipitation ( $38 \mathrm{vs}$. the normal $54 \mathrm{~cm}$ ). In Mediterranean/subtropical production areas (Huett and Stewart, 1999; Munoz et al., 1993; Taylor and van den Ende, 1969), the mild air and soil temperatures may also favor late season $\mathrm{N}$ uptake relative to more typical temperate zone production areas.

The persistence of soil $\mathrm{N}$ availability over the winter following fall fertilization was also supported by the local soil type. Our trees were growing in a Yolo clay loam characterized by a higher percentage organic matter, greater water retention, and a higher cation exchange capacity, etc., than the coarser-textured sandy loams typical of the San Joaquin Valley of California. Thus, under more typical soil and environmental conditions, tree uptake and response to fall-applied $\mathrm{N}$ may have been reduced.

Nitrogen storage, i.e., late season $\mathrm{N}$ accumulation in perennial tree parts is supported by internal and external processes a) $\mathrm{N}$ resorption from senescing leaves prior to natural leaf fall (Blasing et al., 1990; Titus and Kang, 1982), and b) root N uptake from soil prior to natural leaf fall (Millard, 1996; Millard and Thomson, 1989; Tagliavini et al., 1999; Taylor and van den Ende, 1969; 1970; Titus and Kang, 1982; Weinbaum et al., 1978). We are unaware, however, of any previously published work which has quantified the contribution of resorbable leaf $\mathrm{N}$ to $\mathrm{N}$ storage in mature, field-grown Prunus L. and discusses the relative contributions of leaf $\mathrm{N}$ resorption and soil $\mathrm{N}$ uptake to storage. Leaf $\mathrm{N}$ resorption represented $100 \%$ and $39 \%$ of storage $\mathrm{N}$ accumulation in "on" and "off" years of mature alternate-bearing 'Kerman' pistachio (Pistacia vera L.) trees (Rosecrance et al., 1998).

Knowing the leaf $\mathrm{N}$ content per tree (Table 3) and using the widely cited value of $50 \% \mathrm{~N}$ resorption from leaves (Castagnoli, et al., 1990; Conradie, 1986; Oland, 1963; Sanchez and Righetti, 1990; Taylor and van den Ende, 1969; Titus and Kang, 1982), we calculated that leaf $\mathrm{N}$ resorption contributed $\approx 30 \mathrm{~g} \mathrm{~N}$ to the storage pool $(50 \%$ resorption $\times 60 \mathrm{~g}$ leaf $\mathrm{N}$ per tree; Table 3 ). Thus, in our study, large, field-grown, fall-fertilized peach trees contained sufficient resorbable leaf $\mathrm{N}$ to account completely for the $27 \mathrm{~g} \mathrm{~N}$ increase per tree measured in $\mathrm{N}$-deficient peach trees during the previous fall/winter period. These data and calculations suggest that storage $\mathrm{N}$ accumulation may be largely independent of late season root $\mathrm{N}$ uptake. This suggests that leaf $\mathrm{N}$ resorption represents a significant $\mathrm{N}$ source for woody tissue storage, and trees receiving fertilization during spring or summer may not require a fall application to sustain $\mathrm{N}$ reserves in commercial peach orchards in California.

The highest $\mathrm{N}$ concentrations we have seen reported for peach root was $1 \%$ in heavily fertilized trees (Taylor and van den Ende, 1969; see Table 1). To attain that root $\mathrm{N}$ concentration (which could perhaps be considered storage capacity), our roots would have accumulated an additional $\approx 10 \mathrm{~g} /$ tree of $\mathrm{N}$ (calculations based on Table 1). Assuming no change in leaf $\mathrm{N}$ concentration and biomass per tree, leaf $\mathrm{N}$ resorption would still be equivalent to $>80 \%$ of the calculated $\mathrm{N}$ accumulation in perennial tree parts between 29 Sept. 1993 and 15 Feb. 1994.

The contribution of fall fertilization to the increases in N concentrations of perennial tree parts has been demonstrated numerous times in this (Table 1) and previous studies (Tagliavini et al., 1999; Taylor and van den Ende, 1969). What appears to have been missing, however, are discussions of the relative contributions of leaf $\mathrm{N}$ resorption per canopy and late season soil $\mathrm{N}$ uptake to the subsequent performance of mature, field-grown trees. Taylor and van den Ende (1969), concluded that late season $\mathrm{N}$ uptake, $\mathrm{N}$ 
storage, and subsequent spring growth were related causally. They did not, however, compare the spring growth of fall vs. springfertilized trees, nor did they quantify the temporal patterns of tree $\mathrm{N}$ uptake by fall vs. spring-fertilized trees. Tree capacity for $\mathrm{N}$ uptake following the fall fertilizer application is low relative to that during the spring/summer period of fruit and vegetative growth (Table 2) (Huett and Stewart, 1999; Munoz et al., 1993). More than threefourths of the $\mathrm{N}$ ultimately absorbed by fall-fertilized trees persisted in the soil over winter and was absorbed during the subsequent spring and summer. Fertilizer timing did not influence tree performance in the present study even when fertilization of marginally $\mathrm{N}$ deficient trees was withheld until spring. This suggests either that $\mathrm{N}$ storage is nonessential for spring growth resumption and cropping or that adequate storage is not dependent upon fall fertilization and late season soil N uptake. Our data appear to be more consistent with the latter interpretation. The present study indicates that late-season uptake of $\mathrm{N}$ was limited and was nonessential for normal spring foliation and growth when adequate plant-available soil $\mathrm{N}$ was present during shoot growth resumption in spring.

Despite comparable tree performance among fall- and springfertilized trees, heavy fall $\mathrm{N}$ applications may be inadvisable on light textured soils in areas subject to heavy winter rainfall (Tagliavini et al., 1996; Weinbaum et al., 1992). Under those conditions, fall $\mathrm{N}$ applications are likely to be less efficient than spring/summer applications due to winter leaching losses and limited persistence of fall-applied $\mathrm{N}$ in the soil.

\section{Literature Cited}

Amberger, A. 1983. Ways to control the availability, turnover and losses of mineral fertilizer $\mathrm{N}$ in soils, p. 145-169. In: Efficient use of fertilizers in agriculture. Developments in plant and soil sciences. vol. 10. The Hague: Martinus Nijhoff/ Dr. W. Junk for the United Nations.

Beutel, J., K. Uriu, and O. Lilleland. 1983. Leaf analysis for California deciduous fruits. Soil and plant tissue testing in California. Univ. Calif. Bul. 1879.

Blasing, D., D. Atkinson, and K. Clayton-Greene. 1990. The contribution of roots and reserves to tree nutrient demands: Implication for the interpretation of analytical data. Acta Hort. 274:51-69.

Carlson, R.M. 1978. Automated separation and conductimetric determination of ammonia and dissolved carbon dioxide. Anal. Chem. 50:1528-1531.

Castagnoli, S.P., T.M. DeJong, S.A. Weinbaum, and R.S. Johnson. 1990. Autumn foliage applications of $\mathrm{ZnSO}_{4}$ reduced leaf nitrogen remobilization in peach and nectarine. J. Amer. Soc. Hort. Sci. 115:79-83.

Chalmers, D.J. and B. van den Ende. 1975. Productivity of peach trees: Factors affecting dry-weight distribution during tree growth. Ann. Bot. 39:423-432.

Conradie, W.J. 1986. Utilization of nitrogen by the grape-vine as affected by time of application and soil type. S. African J. Enol. Viticult. 7:76-83.

DeJong, T.M., K.R. Day, J.F. Doyle, and R.S. Johnson, 1994. The Kearney Agricultural Center Perpendicular "V" (KA-V) orchard system for peaches and nectarines. HortTechnology 4:362-367.

Hill-Cottingham, D.G. 1963. Effect of the time of application of fertilizer nitrogen on the growth, flowering and fruiting of maiden apple trees grown in sand culture. J. Hort. Sci. 38:242-251.

Huett, D.O. and G.R. Stewart. 1999. Timing of ${ }^{15} \mathrm{~N}$ fertilizer application partitioning to reproductive and vegetative tissue, and nutrient removal by field-grown lowchill peaches in the subtropics. Austral. J. Agr. Res. 50:211-215.

Jenkinson, D.S., R.H. Fox, and J.H. Raynor. 1985. Interactions between fertilizer nitrogen and soil nitrogen—The so-called "priming" effect. J. Soil Sci. 36:425444.

Magness, J.R., L.P. Batjer, and L.O. Regeimbal. 1948. Apple tree response to nitrogen applied at different seasons. J. Agr. Res. 76:1-26.

Millard, P. 1996. Ecophysiology of the internal cycling of nitrogen for tree growth. J. Plant Nutr. Soil Sci. 159:1-10.

Millard, P. and G.H. Nielsen. 1989. The influence of nitrogen supply on the uptake and remobilization of stored $\mathrm{N}$ for the seasonal growth of apple trees. Ann. Bot. 63:301-309.

Millard, P. and C.M. Thomson. 1989. The effect of autumn senescence of leaves on the internal cycling of nitrogen for spring growth of apple trees. J. Expt. Bot. 40:1285-1289.

Miller, H. G. 1986. Carbon $\times$ nitrogen interactions-The limits to productivity. Tree Physiol. 2:373-385.

Munoz, N., J. Guerri, F. Legaz, and E. Primo-Millo. 1993. Seasonal uptake of ${ }^{15} \mathrm{~N}-$ nitrate and distribution of absorbed nitrogen in peach trees. Plant and Soil. 150:263-269.

Oland, K. 1959. Nitrogenous reserves of apple trees. Physiol. Plant. 12:594-648.

Oland, K. 1963. Changes in the content of dry matter and major nutrient elements of apple foliage during senescence and abscission. Physiol. Plant. 16:682-694.

Roberts, R.H. 1921. Nitrogen reserves in apple trees. Proc. Amer. Soc. Hort. Sci. 18:143-145.

Rosecrance, R.C., S.A. Weinbaum, and P.H. Brown. 1998. Alternate bearing affects nitrogen, phosphorus, potassium and starch storage pools in mature pistachio trees. Ann. Bot. 82:463-470.

Saenz, J.L., T.M. DeJong, and S.A. Weinbaum. 1997. Nitrogen stimulated increases in peach yields are associated with extended fruit development period and increased fruit sink capacity. J. Amer. Soc. Hort. Sci. 122:772-777.

Sanchez,E.E. and T.L. Righetti. 1990. Tree nitrogen status and leaf canopy position influence postharvest nitrogen accumulation and efflux from pear leaves. J. Amer. Soc. Hort. Sci. 115:934-937.

Sanchez, E.E., T.L. Righetti, D. Sugar, and P.B. Lombard. 1990. Seasonal differences, soil texture and uptake of newly absorbed nitrogen in field-grown pear trees. J. Hort. Sci. 65:395-400.

Schaffers, A.P. 2000. In situ annual nitrogen mineralization predicted by simple soil properties and short-period field incubation. Plant Soil 221:205-219.

Tagliavini, M., P. Millard, M. Quartieri, and B. Marangoni. 1999. Timing of nitrogen uptake affects winter storage and spring remobilization of nitrogen in nectarine (Prunus persica var. nectarina) trees. Plant Soil 211:149-153.

Tagliavini, M., D. Scudellazi, B. Marangoni, and M. Toselli. 1996. Nitrogen fertilization management in orchards to reconcile productivity and environmental aspects. Fert. Res. 43:93-102.

Taylor, B.K. and B. van den Ende. 1969. The nitrogen nutrition of the peach tree. IV. storage and mobilization of nitrogen in mature trees. Austral. J. Agr. Res. 20:869-881.

Taylor, B.K. and B. van den Ende. 1970. The nitrogen nutrition of the peach tree. VI. Influence of autumn nitrogen applications on the accumulation of nitrogen, carbohydrate, and macroelements in 1-year-old peach trees. Austral. J. Agr. Res. 21:693-698.

Taylor, B.K., B. van den Ende, and R.L. Canterford. 1975. Effects of rate and timing of nitrogen application on the performance and chemical composition of young trees, cv. Williams' Bon Chretien. J. Hort. Sci. 50:29-40.

Titus, J. S. and S. Kang. 1982. Nitrogen metabolism, translocation, and recycling in apple trees. Hort. Rev. 4:204-246.

Tromp, J. and J.C. Ovaa. 1985. Response of young apple trees to time of nitrogen effect with respect to nitrogen, potassium, and calcium levels in xylem sap, new growth and the tree as a whole. J. Plant Physiol. 119:301-309.

Weinbaum, S.A., R.S. Johnson, and T.M. DeJong. 1992. Causes and consequences of overfertilization in orchards. HortTechnology. 2:112-121.

Weinbaum, S.A., I. Klein, F.E. Broadbent, W.C. Micke, and T.T. Muraoka. 1984. Effects of time of nitrogen application and soil texture on the availability of isotopically labeled fertilizer nitrogen to reproductive and vegetative tissue of mature almond trees. J. Amer. Soc. Hort. Sci. 109:339-343.

Weinbaum, S.A., M.L. Merwin, and T.T. Muraoka. 1978. Seasonal variation in nitrate uptake efficiency and distribution of absorbed nitrogen in non-bearing prune trees. J. Amer. Soc. Hort. Sci. 103:516-519.

Weinberger, J.H. and F. P. Cullinan, 1934. Nitrogen uptake and growth responses following fall and spring fertilizer applications. Proc. Amer. Soc. Hort. Sci. 32:65-69.

Westwood, M.N. and A.N. Roberts. 1970. The relationship between trunk crosssectional area and weight of apple trees. J. Amer. Soc. Hort. Sci. 95:28-30.

Williams, R.R. 1965. The effect of summer nitrogen applications on the quality of apple blossom. J. Hort. Sci. 40:31-41.

Youssefi, F., P.H. Brown, and S.A. Weinbaum. 2000a. Relationship between tree nitrogen status, xylem and phloem sap amino acid concentrations, and apparent soil nitrogen uptake by almond trees (Prunus dulcis). J. Hort. Sci. Biotechnol. 75:62-68.

Youssefi, F., S.A. Weinbaum, and P.H. Brown. 2000b. Regulation of nitrogen partitioning in field-grown almond trees: Effects of fruit load and foliar nitrogen applications. Plant Soil 227:273-281. 